\title{
Teachers' perceptions of the impact on students of the Musical Futures
}

\section{approach}

\section{Susan Hallam, Andrea Creech, Hilary McQueen, UCL Institute of Education}

\begin{abstract}
Music education has faced considerable challenges in trying to bridge the gap between music in young people's lives and that taking place in the classroom. The 'Musical Futures' initiative aimed to devise new and imaginative ways of engaging young people, aged 11-19, in music activities through a process of informal learning based on popular music. This research aimed to explore teachers' perceptions of the impact of adopting the Musical Futures approach on students' learning and attainment. Twenty-eight music teachers completed questionnaires and 30 were interviewed. The majority of music staff agreed that since doing Musical Futures students demonstrated higher levels of attainment, greater enjoyment of and positive attitudes towards music lessons, enhanced musical and performance skills, team working, concentration, confidence, listening skills, musical understanding and independent learning.
\end{abstract}

Keywords

Musical Futures, informal learning, teachers perceptions, popular music,

\section{Introduction}

At the beginning of the $21^{\text {st }}$ century in England there was considerable concern about the place of music in the secondary school curriculum. Students showed declining interest in music as they progressed through secondary school and there were low levels of take-up at Key Stage 4 (aged 14 to 16) and at Key Stage 5 (aged 16 to 18) compared with other subjects including those in the arts 
(McQueen \& Hallam, 2010). Although attainment in the General Certificate of School Education (GCSE) music is higher than in other subjects, there continues to be concern about the small number of pupils taking the GCSE in music and the General Certificate of Education (GCE) in music. This lack of take-up does not seem to indicate that students dislike music. Lamont and colleagues (2003) found high levels of enjoyment of music at KS3 even when the inspection body Ofsted graded it as no greater than satisfactory. Students welcomed the opportunity to work practically and make music with their friends and peers and believed that music increased their selfesteem, particularly through performing to others (Ofsted, 2009; Hallam et al., 2009). They and their teachers valued the role of music in the curriculum for its musical and extra-musical benefits (Lamont et al., 2003).

Historically, it was argued that the low level of take-up in secondary school in England when music became optional was because the quality of teaching was poor (Ross, 1995; Harland et al., 2000; Bray, 2000). Certainly, recent Oftsed reports $(2009,2011)$ have shown that there are wide differences in the quality of teaching at secondary level. There are also differences in the uptake of music between schools (Little, 2009) and some evidence that the lack of authenticity and poor links with music outside school is an issue (Bray, 2000; Lamont et al., 2003). Students seem to perceive that music is a highly specialist subject at KS4 and above and that only those with high level instrumental skills will be able to succeed (Lamont et al., 2003; Wright, 2002). There is evidence that some music teachers do discourage pupils who do not have instrumental skills from taking music at KS4 (Ofsted, 2009). Alongside this, students who have high level instrumental skills and pursue music outside of the school curriculum may see no need to continue with music at KS4 unless they wish to pursue a career in music (Little, 2009). The perception of music in the wider community may also be a factor as music is perceived to have little value in career terms (Lamont et al., 2003; Hallam et al., 2009) and parents sometimes discourage their children, particularly boys, from taking it (Button, 2006; Hallam et al., 2009). As a result some have argued that music should 
be removed from the secondary school curriculum and that the focus should be on extra-curricular activity (Sloboda, 2001).

Support for the inadequacy of some of the teaching comes from school inspection data. The 2001/02 Ofsted report on secondary education stated that music lessons exhibited some of the best and worst teaching across all subjects with huge variability in quality. Lessons were described as unimaginative and not related to students' interests. The 2009 report raised similar concerns. Less than half of the schools visited had good or outstanding provision and about $14 \%$ of provision was perceived to be inadequate. While lessons were usually practical and included a range of experiences, students were insufficiently challenged, links between different activities were inadequate and there were too few opportunities for students to deepen their understanding. Students were given opportunities to perform and compose but these tended to focus on musical devices and structures not taking account of the wider context. Schools generally had a set of keyboards and a range of percussion instruments and in some cases there were bass and rhythm guitars, drum kits and/or electronic drum pads. However, schools did not always make best use of these instruments and there was insufficient use of ICT. The most effective teaching was seen in extra-curricular activities and instrumental lessons where the best teachers provided a clear musical learning focus, had high expectations, emphasised quality and provided students with information about how to improve, made excellent use of demonstration, related the work to real life musical tasks, adopted effective questioning and treated everyone as a musician (Ofsted, 2009). The Ofsted report of 2011 indicated that little had changed in the years between 2008 and 2011. While there was some excellent work there continued to be much which was inadequate and some which was barely satisfactory. Of the 90 schools inspected only 35 were rated as good or outstanding. In many lessons there was insufficient emphasis on active music-making with too much verbal communication and too many non-musical activities. The report indicated that where teaching was good and outstanding there was regular classroom work and music making for pupils from all 
backgrounds which was complemented by additional tuition, partnerships and extra-curricular music making.

Finding a way to make class music more relevant to young people in a more learner-centred way has proved challenging. To address this, the Musical Futures (MF) approach was developed to devise new and imaginative ways of engaging young people, aged 11-19, in music activities. It was first implemented as a music education action research project. drawing on research on informal learning generally associated with more popular styles and how they can be used in the classroom (Green, 2002; 2008). Three Pathfinder Local Authority Music Services, in Leeds, Nottingham and Hertfordshire, were commissioned to explore new approaches and structures which might ensure that more young people participated in better quality musical experiences for longer. Two characteristics soon became apparent across the three Pathfinders: that it was important to informalise the way music was often taught, and to personalise the nature of the opportunities on offer (www.musicalfutures,org). From the pilot work four key strands of the Musical Futures programme were developed:

1. Informal Music Learning at Key Stage 3 was based on the real-life learning practices and processes of popular musicians, enabling students to learn alongside friends, through independent, self-directed learning with teachers acting as facilitators and musical models.

2. The Whole Curriculum Approach was a scheme of work for Year 8 students who had not previously experienced sustained musical engagement. Strategies included providing extra support for the teacher, bringing informal learning processes into schools, making tangible connections with students' musical lives outside school, involving students in real musical activity, in genuine musical situations and environments. 
3. Personalising Extra-Curricular Music constituted a guide for personalising extra-curricular music projects so that they complemented the curricular work in schools and enhanced students' musical progression.

4 NUMU. (www.numu.org.uk) provided young people with a safe space for sharing the music that they made enabling peer to peer feedback on their compositions and allowing students to develop skills and apply them to a real life situation with a global audience.

Following the pilot work a toolkit of teacher resources was published which included written materials, such as lesson plans and National Curriculum mapping, video and audio material, as well as case studies and quotes from participating teachers and students (www.musicalfutures.org). A two-year CPD programme was also established followed by the establishment of a national network of 'Champion Schools' that adapted and adopted Musical Futures independently (www.musicalfutures.org). Musical Futures is currently defined as 'an approach to teaching and learning. It is a new way of thinking about music-making in schools that brings non-formal teaching and informal learning approaches into the more formal context of schools' (Musical Futures, 2014, p 9).

A survey of Musical Futures undertaken in 2008 (Hallam et al., 2008) revealed that at that point about 700 teachers were either using or planning to use the Musical Futures materials. The majority of survey respondents reported that they made use of the informal music learning model, although about a quarter either used or planned to use the Whole Curriculum Approach or NUMU with a smaller number using or planning to use the model for Personalising Extra-Curricular Music. The approaches were most often used with Year 9 groups, least frequently with year 7 and typically over the course of an entire academic year. The key expectations of those planning to implement Musical Futures were that it would increase motivation, provide a more stimulating curriculum, raise 
standards, enhance musical skills, provide professional development, and increase the numbers of students taking GCSE Music.

During the pilot stage of Musical Futures when the programme was being implemented in three local authorities, Ofsted (2006) undertook an evaluation. This found that schools welcomed the opportunity to be involved and teachers were enthused by the opportunity to rethink their approach to teaching music. The evaluation indicated that Musical Futures challenged many assumptions about musical learning and offered effective alternatives to established teaching approaches. The evaluation indicated that pupils' motivation increased significantly and that this had a marked positive impact on the whole school. The pupils responded positively to being treated equally as musicians and importantly there were signs of increased take-up of music at GCSE level, although the number of schools involved in the sample was very small.

Since its early days the Musical Futures approach has been adopted more widely and other evaluations have been undertaken. Research in Australia in ten Victorian government schools which had adopted the approach (Jeanneret, 2010) found that teachers' perceptions of the student outcomes were overwhelmingly positive. Teachers felt that there was a positive impact on students' attitudes towards music, self-esteem in relation to music, love of music, group work, on-task behaviour and general behaviour in class. Research on the Musical Futures pilot work in Wales found that teachers had observed enhanced attainment, increased uptake of music at KS4, in some cases an increase in engagement with instrumental lessons and overall greater enthusiaism and commitment from the students (Evans et al., 2015).

The aim of the research reported here was to explore the perceptions of teachers working in England of the impact of adopting the Musical Futures approach on their students in terms of their motivation, well-being, self-esteem, musical self-concept, behaviour and attendance and whether there was any evidence of the development of transferable skills, e.g. in relation to working 
effectively in a team, becoming more confident, becoming an autonomous learner, and enhancing concentration and organisation. The research also sought to explore teachers' perceptions of the impact of Musical Futures on the progression routes available to students and the impact on their extra-curricular learning.

\section{Methodology}

The research was carried out over a three year period in three phases. During Phase 1, questionnaires were completed by music staff in each of six case study schools. In Phases 1, 2 and 3 in-depth individual interviews with Heads of Music and members of the music teaching staff in each case study school were carried out, in order to add insight to the issues that had been raised in the initial Phase 1 questionnaire. The data presented here relate to the Phase 1 questionnaire responses and the interviews undertaken in all three phases.

The questionnaires addressed issues relating to the impact on students, the impact on take-up of GCSE music, and the impact on take-up of extra-curricular instrumental and vocal activities. A data base was created for use with SPSS to include the data from the questionnaires, enabling a wide range of analyses to be undertaken. The qualitative data were used to provide more in depth insights in relation to the questionnaire responses. For authenticity, the quotes from the teachers are presented verbatim which means that there may be grammatical errors within them. A member of the research team visited the participant schools for the purposes of administering and collecting questionnaires, undertaking focus group interviews and interviews with staff, and observing musical activities.

\section{The sample}

Six case study schools were selected for the research in consultation with the Musical Futures team to represent different types of school and lengths of experience with Musical Futures. The schools 
differed in their characteristics and the ways in which they were implementing Musical Futures.

They had in common a Head of Music who saw the value of Musical Futures and was committed to its implementation. They were also all Musical Futures Champion schools.

During Phase 1 of the research, 28 music teachers, representing a range of experience of Musical Futures, completed a questionnaire. The number of responses from music teachers in each school varied from one to six. Six responses (21\%) were from Heads of Music, nine (32\%) from full- time music teachers, four (14\%) from part-time teachers, two (7\%) from trainee teachers on PGCE placements, four (14\%) from technicians and three (12\%) from those describing their positions in other ways. The teachers played a variety of instruments the most common being piano/keyboard (see Table 1).

Table 1: Instruments played by music staff

\begin{tabular}{|l|l|l|c|c|c|c|c|c|}
\hline & $\begin{array}{l}\text { First } \\
\text { instrument }\end{array}$ & $\begin{array}{l}\text { Second } \\
\text { instrument }\end{array}$ & $\begin{array}{l}\text { Third } \\
\text { instrument }\end{array}$ & $\begin{array}{l}\text { Fourth } \\
\text { instrument }\end{array}$ & \\
\hline Voice & 3 & $11 \%$ & 2 & $8 \%$ & 1 & $5 \%$ & 2 & $20 \%$ \\
\hline Piano/Keyboard & 7 & $26 \%$ & 8 & $32 \%$ & 5 & $26 \%$ & 1 & $10 \%$ \\
\hline Brass instrument & 3 & $11 \%$ & & & 1 & $5 \%$ & 1 & $10 \%$ \\
\hline String instrument & 3 & $11 \%$ & 3 & $12 \%$ & 1 & $5 \%$ & & \\
\hline Woodwind & 5 & $18 \%$ & 3 & $12 \%$ & 4 & $21 \%$ & 3 & $30 \%$ \\
\hline Percussion & 3 & $11 \%$ & 1 & $4 \%$ & 5 & $26 \%$ & 1 & $10 \%$ \\
\hline Guitar & 3 & $11 \%$ & 7 & $28 \%$ & 2 & $10 \%$ & 2 & $20 \%$ \\
\hline Organ & & & 1 & $4 \%$ & & & & \\
\hline
\end{tabular}

Eighty five percent (24) of teachers had attained grade 8 on their first instrument and 87 percent (25) on their second instrument. Fifty percent (14) had attained grade 8 on their third instrument. Fewer teachers played a fourth instrument and the standard here was lower at grade 4 or 5 . Seventy one percent (20) of the teachers participated in some kind of musical group, 46\% (13) in two groups and 21\% (6) in three groups. Eight (29\%) played in an orchestra, six (21\%) sang in a choir, six $(21 \%)$ played in a rock/pop band, five in a funk/jazz/disco band, three (11\%) in a brass band and three $(11 \%)$ in a chamber music group. Individuals also played in unspecified ensembles, a wind 
band, a show band, a steel band and engaged in Taiko drumming. Two were conductors and one an accompanist.

Ninety one percent (25) of respondents indicated that they had an A level music qualification, $31 \%$ (9) had a music diploma, and 95\% (26) had a music degree. Other qualifications held included an MA, a PGCE or a Certificate in Education.

Eighteen percent (5) of the music teachers indicated that they used Musical Futures with Year 7, $79 \%$ (22) with Year 8, 79\% (22) with Year 9, 4\% (1) with Year 10 and 14\% (4) with Year 11. Thirty nine percent (11) used the Whole Curriculum Approach, 75\% (21) used informal music learning at Key Stage 3, 57\% (16) used NUMU, and 7\% (2) used Personalising the curriculum. Forty three percent (12) used Musical Futures for the whole academic year, 29\% (8) for one term, $11 \%$ (3) for one or more units of work and 4\% (1) for an occasional lesson. The number of years of teaching experience varied from 0 to 28 . The most experience of working with Musical Futures was five years (2 teachers). Some teachers had been involved in the pilot work (see Table 2).

Table 2: Music Teachers' experience of working with Musical Futures

\begin{tabular}{|l|c|c|}
\hline Length of time & Number & Percentage \\
\hline Involved in pilot & 1 & 4 \\
\hline 5 years & 2 & 9 \\
\hline 3 years & 2 & 9 \\
\hline 2 years & 2 & 9 \\
\hline 1 year & 4 & 17 \\
\hline 2 terms & 4 & 17 \\
\hline 1 term & 3 & 13 \\
\hline While on teaching practice & 1 & 4 \\
\hline Some/a little & 2 & 9 \\
\hline None & 2 & 9 \\
\hline
\end{tabular}




\section{Findings}

\section{Perceived impact on students}

Table 3 sets out the numbers and percentages of music staff agreeing or disagreeing with a range of statements relating to the impact of participating in Musical Futures on students. The means and standard deviations are also included.

Table 3: Perceived impact on students

\begin{tabular}{|l|l|l|l|l|l|l|}
\hline $\begin{array}{l}\text { Since doing Musical Futures my } \\
\text { students: }\end{array}$ & $\begin{array}{l}\text { Strongly } \\
\text { agree }\end{array}$ & Agree & Disagree & $\begin{array}{l}\text { Strongly } \\
\text { disagree }\end{array}$ & Mean & SD \\
\hline $\begin{array}{l}\text { Demonstrate higher levels of } \\
\text { attainment }\end{array}$ & $36 \%(8)$ & $41 \%(9)$ & $23 \%(5)$ & & 3.1 & .8 \\
\hline Enjoy their music lessons & $22 \%(6)$ & $71 \%(19)$ & $7 \%(2)$ & & 3.1 & .5 \\
\hline Want to do well & $19 \%(5)$ & $74 \%(20)$ & $7 \%(2)$ & & 3.1 & .5 \\
\hline $\begin{array}{l}\text { Work better when they work with } \\
\text { their friends }\end{array}$ & $19 \%(5)$ & $42 \%(11)$ & $39 \%(10)$ & & 3.2 & .7 \\
\hline Are able to stay on task & $4 \%(1)$ & $59 \%(7)$ & $26 \%(7)$ & $4 \%(1)$ & 2.8 & .7 \\
\hline Are confident & $4 \%(1)$ & $82 \%(22)$ & $15 \%(4)$ & & 2.9 & .4 \\
\hline $\begin{array}{l}\text { Have developed a wider range of } \\
\text { musical skills }\end{array}$ & $20 \%(5)$ & $52 \%(13)$ & $28 \%(7)$ & & 2.9 & .7 \\
\hline $\begin{array}{l}\text { Have developed a good } \\
\text { understanding of a range of musical } \\
\text { genres }\end{array}$ & $4 \%(1)$ & $41 \%(11)$ & $44 \%(12)$ & $11 \%(3)$ & 2.4 & .7 \\
\hline Create good musical performances & $37 \%(10)$ & $52 \%(14)$ & $11 \%(3)$ & & 3.3 & .7 \\
\hline Demonstrate good listening skills & $35 \%(9)$ & $58 \%(15)$ & $8 \%(2)$ & & 2.7 & .6 \\
\hline $\begin{array}{l}\text { Have positive attitudes towards } \\
\text { music }\end{array}$ & $33 \%(9)$ & $56 \%(15)$ & $11 \%(3)$ & & 3.2 & .6 \\
\hline $\begin{array}{l}\text { Are generally well-behaved in } \\
\text { music lessons }\end{array}$ & $19 \%(5)$ & $70 \%(19)$ & $11 \%(3)$ & & 3.1 & .5 \\
\hline $\begin{array}{l}\text { Can work well without help from } \\
\text { me }\end{array}$ & $31 \%(8)$ & $46 \%(12)$ & $23 \%(6)$ & & 3.1 & .7 \\
\hline $\begin{array}{l}\text { Work together effectively in music } \\
\text { tasks }\end{array}$ & $19 \%(5)$ & $73 \%(19)$ & $8 \%(2)$ & & 3.1 & .5 \\
\hline Help others during the lesson & $19 \%(5)$ & $70 \%(19)$ & $11 \%(3)$ & & 3.1 & .5 \\
\hline Attend music lessons regularly & $61 \%(16)$ & $39 \%(10)$ & & & 3.4 & .5 \\
\hline $\begin{array}{l}\text { Have mostly exceeded my } \\
\text { expectations when it comes to } \\
\text { improving their musical skills }\end{array}$ & $33 \%(9)$ & $48 \%(13)$ & $19 \%(5)$ & & 3.1 & .7 \\
\hline $\begin{array}{l}\text { Have high levels of self-esteem in } \\
\text { relation to music }\end{array}$ & $28 \%(7)$ & $40 \%(10)$ & $32 \%(8)$ & & 3.0 & .8 \\
\hline Don't need much help from me & $11 \%(3)$ & $62 \%(16)$ & $27 \%(7)$ & & 2.8 & .6 \\
\hline Fulfil their musical potential & $15 \%(4)$ & $69 \%(18)$ & $15 \%(4)$ & & 3.0 & .6 \\
\hline Demonstrate that they love music & & & & & \\
\hline NB The & & & & & & \\
\hline
\end{tabular}

NB The numbers in brackets indicate the number of responses 


\section{Self-esteem and confidence}

Teachers commented on the enhancement of self-esteem and self-confidence in some students, particularly those who were normally quiet and shy:

'I think it certainly helps their self-esteem. Because there are some students who are really shy and sort of sit in a corner and haven't got much musical ability. If they're doing something like Musical Futures, even if it's playing one note on a piano over and over again or a drum part, they're doing something.' (Head of Music School F)

'I think it's given a lot of confidence to students. There are quite a number of instances of very quiet kids who are very good musically who often don't get a chance to shine in normal lessons. There are concerts and performances now where they can excel.' (Head of Music School A)

There were also examples of difficult students developing enhanced confidence and self-esteem as a result of their successes in music:

'I had an example this morning of a girl with real attitude. I said 'I've heard you're a really good

singer." I spent time with them today and she started singing and I said "that's brilliant". You could see this girl just melt and I said "you're going to perform first today because you're the best" and they did and they performed and everyone was like, "yeah", bigging her up, and I thought “where else is she going to get that”. ' (Head of Music School C)

Other staff commented on the general atmosphere in classes: 
'They seem to be happy, they seem to be content in the lesson. Their self-confidence, working with their friends there's a general feeling of well-being because they're with their mates.' (Music Teacher School F)

\section{Transferable skills}

Teachers recognised a range of transferable skills that students developed as a result of engagement with Musical Futures. Students being able to organise their activities was frequently mentioned:

'They've got to be organised to do this. They've got to be responsible for setting up, they need to have their recordings every time, their words, they need to have their tabs, bring an instrument in from home. They need to get themselves into a room, sort the equipment out before they start. When they're rehearsing they need to be organised rather than playing at the same time. Concentration, the lesson seems to go much quicker for the kids because they're into it and concentrating on what they're doing. It's hard. It's not an easy skill.' (Head of Music School A)

'Recently, some of the girls wanted to put a concert on for charity and they organised that themselves, so organisation skills and life skills as well.' (Music Teacher School A)

\section{Motivation}

A key perceived benefit of Musical Futures was that it enhanced motivation:

'My most successful Musical Futures lessons are band work because kids who've had no interest in music, it's relevant to them, suddenly they get it.' (Head of Music School C) 
I'm thinking of a couple of kids who are a bit of a handful. In Year 8, we started Eleanor Rigby, they got really into the idea of working together, did great work together, and now they've carried on that attitude into the keyboard work and now [they are] probably two of the better keyboard players in that class and it feels like it's come from their enjoyment of one particular unit.' (Music Teacher School D)

The increased motivation seemed to occur because of the degree of choice students had to follow their own interests:

'The learners can make their own choices and follow their own interests so it motivates them more. In the past Year 9 were quite disaffected but now it motivates them more.' (Music Teacher School A)

The fact that the students were able to take ownership of the work, and the teacher was merely providing support was empowering:

'It's been very successful, it's been a good motivator for the kids. They like the fact that it's their work and I'm just a helper, someone who comes round and helps but they've decided what they're going to do. It really motivates them.' (Head of Music School A)

The increased motivation led to more practise and speedier progress:

'Students progress more quickly because quite a lot of them will practise more in their own time because they're more motivated, more interested, beginning to see it more as a hobby, they will do things by themselves.' (Music Teacher School A)

More students were spending time practising in break-times: 
'There are more kids coming to the open session at lunchtime. Since we've been doing Musical Futures we definitely get more people coming along with their own band things to do.' (Music Teacher School D)

'Kids really like it, it's really popular. Kids stay back all the time and practise and they come in at dinner-time or they want to sign up for peripatetic lessons or something.' (Head of Music School D)

There were also benefits for behaviour:

'Because they're motivated they actually want to work and their behaviour improves and I don't think they realise their behaviour's improving, they just are more motivated and it just comes with that.' (Music Teacher School F)

There were examples where increased motivation had contributed towards improved attendance:

'There's a kid in my form, J, whose attendance is terrible. I am monitoring his attendance on those days we have music. I've put him in a little band. He's in Year 8 and I've put him in a band with everybody else who's in Year 9. We rehearse that band on days we don't have music. I've done that on purpose. I know he's going to attend even though his parents are being taken to court about his attendance. When he has music he's here, and he's never away when we have band practice and at lunchtimes he's in here practising guitar.' (Head of Music School D) 


\section{Inclusion}

Most of the teachers $(64 \%, 18)$ believed that Musical Futures could work with classes of all sizes. However, an analysis of variance showed that there were statistically significant differences between schools in responses $(\mathrm{p}=.005)$. Fifty-six percent 16$)$ of teachers agreed that Musical Futures could work equally well with all students but there were school differences. Teachers provided examples of inclusion:

'I think everybody's benefited. You could think, loud students will be good at doing it, but it's been everybody. I took photos of my form and my favourite picture is two Muslim girls, one singing and the other's playing the drums.' (Head of Music School D)

Some teachers felt that particular groups benefited:

'I think it's probably more beneficial to middle end, lower end ability rather than the top end.' (Head of Music School F)

The gender imbalance was noted by some teachers:

'We're boy heavy. Part of me embraces that because we know boys are failing and we know in a sense they're the ones that need to be supported. But I would hate if Musical Futures was something that turned girls off music. I think that's something that needs to be looked at or that may happen.' (Head of Music School C)

'The boys are more confident than they used to be. I think if you looked at our GCSE groups and gender, we tend to be sort of fairly equal on that, and fairly equal success actually.' (Music Teacher School F) 
Some teachers felt that that there could be barriers for some students in terms of special educational needs:

'I think some students can benefit more than others and some might find it difficult, for instance, some with particular needs who need one to one attention or there might be students that you cannot leave in a room without a teacher. There might be some that don't have the skills to get on with it.' (Music Teacher School D)

'There's been two kids who have found the freedom difficult, one who is actually on the autism spectrum, and I think there's another two children I teach on the autism spectrum who don't enjoy it.' (Head of Music School C)

Another teacher pointed out that some students found performing difficult:

I've got one student in Year 7 who almost has a panic attack situation when it comes to performing in front of others.' (Music Teacher School C)

Those with poor behaviour were identified as particularly problematic:

'I think the students that need your support behaviour-wise they cannot cope with the freedom at all. You might have two or three in a classroom of 27 who do not cope with that freedom.' (Head of Music School E)

Some teachers expressed concern about the high achievers: 
'The really talented students excel by doing their own part or by becoming leader of the group and help others. I must admit I think probably one weakness of Musical Futures is dealing to the higher end. You need to think quite a lot more what the best students can actually do. It depends what piece they choose. For example, when they choose their piece and try to recreate it and it's quite simple, that is going to limit a really good student, whereas if they pick something challenging, that's going to challenge them.' (Music Teacher School C)

Although others saw this as an opportunity for high achievers:

'Emma, who's grade 7 piano, she's on the drums in band lesson and she loves it and I think it can be quite liberating for those sort of gifted and talented musicians to branch out in different areas.' (Head of Music School E)

'One of the girls came to the school with a grade 7 violin grade. However she hasn't ever written any music or composed or anything or led anything or worked out harmonies or anything like that. She took a liking to playing the drums. She was really struggling at first but she wanted to do it. In some ways it put her on a par with everybody else in the group and she's also enjoying it.' (Head of Music School C)

\section{Listening skills}

In the interviews teachers indicated the ways in which students improved their listening skills:

'Listening skills improve because they're trying to fathom things out from here or they're trying to recreate something that somebody else has done so they tend to really listen to what parts are. Listening skills and obviously instrumental skills develop slowly throughout the course of Key Stage 3. ' (Music Teacher School B) 


\section{The role of performance}

Performance is an essential part of Musical Futures and is fully integrated with listening, composing and improvising (www.musicalfutures.org). Two of the schools already placed great emphasis on performance to the wider school and in public concerts. The Musical Futures approaches supported this:

'Musical Futures has increased the number of people wanting to perform. In some schools, places where Musical Futures doesn't exist, students are really shy about performing, but Musical Futures gives them the confidence. It's something they want to do first of all because it's their music. They realise they can make a good job of it so they want to perform it and show other people.' (Head of Music School F)

The teachers found that the performances validated the work that they were doing in their music departments:

'You've just got to look at the Key Stage 3 showcase, I mean those evenings are wonderful. I have tears in my eyes at the end of it. It's just "wow"'. (Music Teacher School B)

The performance aspect was particularly successful in focusing the students on their work:

'I think the performance aspect of it is really important. The students know that at the end they have to perform. They've got $x$ number of weeks and then they're going to perform. At the back of their mind they're thinking, well, hang on, in a few weeks time I'm actually going to have to stand up in front of my classmates, my peers, and perform, so there's an impetus to really get something done. 
There's the motivational aspect of "well actually I don't want to look stupid, better sort something out".' (Music Teacher School B)

\section{Independent learning}

Teachers raised issues relating to the extent to which students were able to work independently and how important this was. Some provided guidance to their students on setting specific targets for each lesson:

'With Musical Futures it's totally thrown into their hands really, what they do for it, their control. The first couple of lessons often are completely chaotic in the way that no one really knows what they're actually doing. It seems chaotic but by lesson 3 you can see they're actually working really, really well.' (Head of Music School F)

Being put in a situation where they needed to work independently could support personal development, although for some it proved difficult:

'I think it can make them think more, it can make them more confident. They have to decide which instrument they're going to play and stick to that. Also keep up with the other members of the band. If they're doing the vocals there's more pressure on them to do it well. It's quite a personal thing. It's not like playing the keyboard. I think the songwriting as well, that was pushing themselves to be more creative and then having the motivation to see it through over a number of weeks, mainly looking at the same part again and again and again. For some of them it's been difficult to be more independent, if they're all lined up playing keyboards next door, they find it easy to go miss, miss, miss, miss, miss, before they've thought what they want to ask, so learning to be more independent.' (Music Teacher School D) 


\section{Progression}

Teachers spoke of progression in terms of the challenges that students faced and how they progressed in meeting them:

'Take a notation-reading flute player, take away their notation and their flute and give them something else to do and it becomes much more challenging. If you have a very able musician in the group, taking a lead in organising other people and sharing their skills can be challenging as well. It's encouraging them off their preferred instrument to explore and do other things. So you can push the more able kids and we do see them thrive. The least able, if the teacher gets in there at the right moment and gives the right support, they can achieve something which is just fantastic and that's great for motivation and great for everybody, and they do make progress. But it does depend $100 \%$ on the teacher doing their job properly.' (Head of Music School E)

Staff reported that the group work enabled them to assess progress more easily and spot those who were developing considerable musical skills:

'You quite often find that you discover a real talent that you weren't quite aware of before. A couple of weeks ago there was a girl, in Year 9, I didn't know she could sing and play at the same time.' (Music Teacher School A)

'We spotted X through the band project in Year 8, unbelievable singer, and he's such an unassuming character. Anyway we did this lesson and I was blown away by this boy's voice and I thought "wow". He's doing music now at key stage 4 and he just took the lead role in the musical, the Wizard of $\mathrm{Oz}$, the Whizz King.' (Music Teacher School B) 
The independence that students were given and the opportunities that they had for working on projects of their own choosing were also seen as important alongside their success:

'I think that boys that were achieving low grades in music, because they've been allowed to do what they've wanted to do, it's really sparked their enthusiasm. Certainly at the lower end it's certainly lifted attainment I would say, particularly boys.' (Head of Music School F)

\section{Progression to Key Stage 4}

In five of the schools the teachers commented favourably on the increase in the number of students continuing with music after Key Stage 3 as a result of Musical Futures:

'We lose less students at the end of Year 9 than we used to.' (Head of Music School D)

'This year in Year 10 we have 44 choosing to do GCSE music, compared with 23 two years ago. Alevel music, much increased uptake. BTEC (Business and Technology Education Council), which I've introduced at Key stage 5, we've had 11 this year and we've got 14 next year. So at Key stage 5 we've got over 20 people choosing to do music.' (Head of Music School C)

It's been steadily increasing ..... it's kind of upped since Musical Futures..... For KS4 we have to turn kids away every year who want to study music to do our BTEC level 2.' (Music Teacher School B)

We've definitely seen an increase in numbers. When I first came here six years ago there were about 16 people in the GCSE group and now we're about 40 every year.' (Music Teacher School A) 
Historically, five years ago music was twighlight, it was cherry-picked students who had to be grade 5 or higher. We've got 40 doing GCSE which is our biggest uptake for some time and I think that's because this group have come through and have been taught in the Musical Futures way since Year 7.' (Head of Music School E).

In school F there was no great increase as the numbers taking GCSE had always been good: 'I think they've progressed. GCSE? Yes, numbers have gone up this certainly on last year, not amazingly but we get good numbers anyway. We've always had fairly strong numbers for GCSE.' (Head of Music school F)

In some cases broader changes in the school affected recruitment:

'Last year we had a sizeable amount, we had about 32 start it, from about 200 in a year group. This year we've had it drop quite a lot and we've got about 7 or 8 doing rock school and we've got about 15 doing GCSE music. One massive reason for that is option blocks. We went down from four option blocks to three so that they would have more hours in each subject, and music that was the one people calling up and saying "is there a creative one? We've chosen the academic ones and we need that extra option block to do our creative subject but they couldn't do it." Hopefully higher grades and that's what the school is looking for. So many parents called to say "we're going to have to drop it."' (Head of Music school E)

\section{Discussion}

The findings from this research support the research on Musical Futures undertaken in Australia by Jeanneret (2010) and in Wales by Evans et al. (2015). The majority of music staff agreed that since the adoption of the Musical Futures approach students demonstrated higher levels of attainment, greater enjoyment of and positive attitudes towards music lessons, enhanced musical and performance skills, team working, concentration, confidence, listening skills, musical understanding 
and independent learning. The focus on active music making and performance enabled teachers to identify those with high level musical skills acquired outside of the formal school system who might otherwise have remained unrecognised enabling them to fulfil their potential. Adoption of the approach also increased the number of students opting to take music at KS4. Clearly, there are many benefits of a curriculum which offers practical music making, taking account of young people's musical preferences, and is inclusive, supporting all students in actively engaging with music.

Much of the appeal of the Musical Futures approach from the student perspective has been its focus on rock/pop music. There has been a suggestion that such informal learning should include more digital work. Väkevä (2010) suggests including such practices as DJing/turntablism, assembling of various bits and pieces to remixes, remixing entire songs to mash-ups in home studios, collective songwriting online, producing one's own music videos to YouTube, and exchanging and comparing videos of live performances of Guitar Hero and Rock Band game songs. These activities it is argued are more representative of the current nature of much popular music than the garage band.

The research has a number of limitations. It was undertaken in schools which were Musical Futures champion schools where staff were committed to the approach and had a wide range of instrumental and musical skills enabling them to engage with rock/pop music. The focus on such a small number of schools may have distorted the findings leading to a focus on the positive outcomes of Musical Futures and not taking sufficient account of the difficulties.

The challenges facing music teachers implementing informal approaches to teaching music should not be underestimated. These have been set out by Gower (2012), a practitioner who identifies the difficulties that music teachers adopting informal approaches face in the heavily attainment driven English education system. She argues that ways need to be found to integrate informal approaches which satisfy the needs of all young people into the target-driven priorities of schools. Hallam et al. 
(submitted) have identified similar pressures also highlighting how exhausting it is for teachers to engage with the workshopping approach required to implement Musical Futures on a daily basis.

Teachers also need to have appropriate instrumental and musical skills to enable them to engage with rock/pop music which typically constitutes the starting point for the implementation of the Musical Futures approach. Not all musicians have these skills when they enter the teaching profession. This raises issues relating to the initial and ongoing Continuing Professional Development of music teachers who are adopting informal approaches. Finney and Philpott (2010) propose that a meta-pedagogy which embraces informal learning and pedagogy in music needs to be developed. They argue that student teachers need to be supported to use theoretical tools to reflect on their 'lived' experience, to develop theories based on their experiences and to encourage the mutual interrogation of theory and experience. They demonstrate how this can be implemented and the ways that students responded to it. Their approach reflects that needed by teachers to implement the Musical Futures approach.

There were indications that the success of Musical Futures in terms of increasing take up at KS4 depended on factors outside the control of music teachers, for instance, the combination of choices available when students had to select the subjects which they wanted to take. The choices available are in turn influenced by political decisions about the nature of assessment at KS4, for instance, the introduction of the English baccalaureate and changes in the vocational qualifications which schools are able to take into account in setting out their academic performance for public scrutiny. These have major implications not only for the implementation of Musical Futures but for music education more generally and require continuing advocacy activities on the part of musicians.

\section{Conclusion}

Overall, the Musical Futures approach has the potential to transform music education in schools, and raise self-confidence, attainment and motivation. It enhanced progress and increased the 
number of students opting for music at KS4. The approach enabled students to develop a range of transferable skills, created a positive working environment in classes and improved behaviour.

Although the approach was inclusive, some groups were perceived as benefitting more than others.

Key to the success of Musical Futures was the impact on motivation which was enhanced through students being given choice, taking ownership of their learning and working independently towards giving a performance to their peers. If the approach is to be implemented widely music teachers need to receive appropriate initial and ongoing training and schools need to recognise the stresses of managing workshopping on a continuous basis and make allowances for this in timetabling and levels of staffing.

\section{References}

Bray, D. (2000) 'An examination of GCSE music uptake rates'. British Journal of Music Education, 17(1), 79-89.

Button, S. (2006) 'Key Stage 3 pupils' perception of music'. Music Education Research, 8(3), 417431.

D’Amore, A. (ed) (2014) Musical Futures: An approach to teaching and learning. Resource Pack $2^{\text {nd }}$ edition. London: Paul Hamlyn Foundation

Evans, S.E., Beauchamp, G., \& John, V. (2015) Learners' experience and perceptions of informal learning in Key Stage 3 music: a collective case study, exploring the implementation of Musical Futures in three secondary schools in Wales. Music Education Research, 17(1), 1-16.

Finney, J \& Philpott, C. (2010) Informal learning and meta-pedagogy in initial teacher education in England, British Journal of Music Education, 27(1), 7-19.

Gower, A. (2012) Integrating informal learning approaches into the formal learning environment of mainstream secondary schools in England. British Journal of Music Education, 29(1), 13-18.

Green, L. (2002) How Popular Musicians Learn: A Way Ahead for Music Education. Aldershot: Ashgate Publishing Ltd.

Green, L. (2008) Music, Informal Learning and the School: A New Classroom Pedagogy. Aldershot, Ashgate Publishing Ltd.

Hallam, S., Creech, A., Sandford, C., Rinta, T. and Shave, K. (2008) Survey of Musical Futures: A report from Institute of Education, University of London for the Paul Hamlyn Foundation. London: Institute of Education, University of London

Hallam, S., Creech, A and McQueen, H. (2009) Musical Futures: A case study investigation, an interim report from the Institute of Education, University of London for the Paul Hamlyn Foundation. London: Institute of Education. 
Hallam, S., Creech, A and McQueen, H. (submitted) What impact does teaching music informally in the classroom have on teachers, and their pedagogy? Music Education Research.

Harland, J.Kinder, K., Lord, P., Stott, A., Schagen, I., Haynes, J., with Cusworth, L., White, R., \& Paola, R. (2000) Arts Education in Secondary Schools: Effects and effectiveness. Slough: National Foundation for Educational Research.

Jeanneret, Neryl. Musical Futures in Victoria [online]. Australian Journal of Music Education, No. 2, Dec 2010: 148-164. Availability: $\leq$ http://search.informit.com.au/documentSummary; $\mathrm{dn}=813591038166404 ;$ res=IELHSS >ISSN: 00049484. [cited 24 Jan 15].

Lamont, A., Hargreaves, D.J., Marshall, N.A., and Tarrant, M. (2003) 'Young people's music in and out of school', British Journal of Music Education, 20(3), 229-241.

Little, F. (2009) 'An Exploration into the Uptake Rates of GCSE Music with a Focus on the Purposes of Music in School'. Unpublished EdD thesis, University of Durham.

McQueen, H. \& Hallam, S. (2010) Music in the secondary school. In S. Hallam \& A. Creech (eds) Music Education in the $21^{\text {st }}$ Century in the United Kingdom: Achievements, analysis and aspirations. London: Institute of Education, University of London.

Ofsted (2003) Music in Secondary Schools: Ofsted subject reports series 2001/02 (HMI 811). London: Ofsted.

Ofsted (2006) An Evaluation of the Paul Hamlyn Foundation's Musical Futures Project (HMI 2682). London: Ofsted.

Ofsted (2009) Making More of Music: An Evaluation of Music in Schools 2005/08. London: Ofsted.

Ofsted (2011) Music in schools: wider still and wider. Quality and inequality in music education 2008-2011. London: Ofsted.

Ross, M. (1995) 'What's wrong with school music'. British Journal of Music Education, 12(3), 185-201.

Sloboda, J. (2001) 'Emotion, functuality, and the everyday experience of music: where does music education fit?. Music Education Research, 3(2), 243-254.

Väkevä, L. (2010). Garage band or GarageBand ${ }^{\circledR}$ ? Remixing musical futures. British Journal of Music Education, 27(1), 59-70.

Wright, R. (2002) 'Music for all? Pupils perceptions of the GCSE music examination in one South Wales secondary school', British Journal of Music Education, 19(3), 227-241. 